\title{
ECONOMIC REFORMS IN 1970S COLOMBIA: ASSESSING THE STRATEGIC ROLE OF LÓPEZ MICHELSEN'S GOVERNMENT AND THE COFFEE BOOM*
}

\author{
ANGELA M. ROJAS RIVERA \\ Universidad de Antioquia $^{\mathrm{a}}$
}

\begin{abstract}
In this article I build an analytic narrative to provide an integrated and analytical view of the economic reforms that took place in Colombia during the years 1974-1978. Through the use of basic game theory and historical evidence, I present the core of the strategic interactions between several players: Government is depicted as a committed but poorly endowed agenda setter, Coffee as the dominant player and Industry as the contending but relatively weak player. The analysis shows that the 1976 coffee boom changed the interaction between sectors from an assurance to a prisoner's dilemma game, and identifies as the post-boom solution the GovernmentCoffee coalition, which carried out a soft version of the initial reforms.
\end{abstract}

Keywords: analytic narratives, economic reform, Colombian history, Alfonso López Michelsen

JEL Classification: D78, E65, N16

* Received 29 July 2014. Accepted 31 March 2015. The author very much appreciate the research assistance of Juan Camilo Alvarez and Juan Gabriel Vanegas and thank Ivan Andrés Martinez for his assistance in newspaper reviews. The comments and suggestions of Paul J. Johnson and David Mares were especially useful. As always, the errors are exclusively mine. The author acknowledge the support of the Vicerrectoria de Docencia of the Universidad de Antioquia.

a Department of Economics, Ciudad Universitaria, Calle 67 \# 53-108, Bloque 13, Oficina 413 , Medellín, Colombia. amilena.rojas@udea.edu.co. 


\section{RESUMEN}

En este artículo elaboro una narrativa analítica que ofrece una mirada integrada y analítica de las reformas económicas en Colombia durante 19741978. A través del uso de teoría de juegos básica y de evidencia histórica, represento el núcleo de la interacción estratégica entre varios jugadores: el gobierno aparece como un jugador comprometido pero pobremente dotado en tanto ponente de la agenda, Café como el jugador dominante y la Industria como jugador contendiente pero relativamente débil. El análisis muestra que el boom cafetero de 1976 cambió la interacción entre los sectores de un juego de la confianza a un dilema del prisionero, e identifica como la solución de post-boom la coalición Gobierno-Café que implementó una versión moderada de las reformas iniciales.

Palabras clave: Narrativas analíticas, reformas económicas, historia de Colombia, Alfonso López Michelsen

\section{INTRODUCTION}

Reformist winds in 1970s Colombia were motivated by criticisms of the welfare state and Keynesian policies coming from the United States and the United Kingdom. This new policymaking emphasised lesser state intervention, market efficiency, macroeconomic stability and trade openness, while inflationary control was made a priority in the new international monetary order. In Colombia, the presidential candidate Alfonso López Michelsen (ALM) introduced these ideas in the 1974 elections (López 1975). This rhetoric was appealing because the bottleneck created by import-substituting industrialisation (ISI) policies was tightening, while foreign capital inflows were increasing and industrial exports were booming. Colombian economic sectors, to different extents, expressed their enthusiasm for participating in the international market expansion, and deemed the volatility of inflation and fiscal deficits as undesirable features that must be eliminated. Consequently, ALM was elected president in 1974.

Four years after ALM became president, results showed that inflation had increased permanently, trade protection had been lowered slightly for the principal industries, manufactured exports had diminished and tended towards decline, capital investment was paralyzed, public transfers to the private sector had increased and direct tax revenues had shrunk. There was a bitter taste in the air from what had been labelled as neoliberal policies. Furthermore, in the 1970s, the country experienced a turning point in its economic performance as high growth rates from years of ISI were left behind. 
Why did the country take the path of moderate reformism? What were the consequences of taking this path? Accounts of this epoch highlight some of the reasons, which can be grouped into three categories: exogenous shocks, implementation issues and interest groups. In the first category, two international shocks took place: the 1974 oil shock and the 1976 coffee boom. The oil shock imposed harsh economic conditions just when the government was engaging in tight fiscal and monetary policymaking. This fact made it much more difficult to undertake a stabilisation plan. In contrast, the 1976 coffee boom brought extra trade income, providing incentives to relax macroeconomic policies (Bejarano 1984; Gomez and Leibovich 1987; Clavijo 1992; Ocampo 1996).

The second category includes factors such as the scope, order and timing of implementing specific policies (tax reform and trade liberalisation). Along these lines, the reforms were clumsily applied and were thereafter derailed by short-term concerns. In addition, the institutional structure of economic policymaking inherited from state-led industrialisation appeared to be an obstacle for consistent and sustained implementation (Misas 1980; Martinez 1986; Garay 1998). The third, and less explored, category refers to the response of interest groups to the reforms. In this line, authors underscore conflicts between economic groups, political tensions and political corruption (Ardila 1978; Echeverri 1987; Edwards 2001).

Undoubtedly, these causes interconnect. The objective of this research is, specifically, to provide an integrated and systematic view of the adoption of the 1974-1978 economic reforms in Colombia. Moving from descriptive accounts or purely macroeconomic analysis to a comprehensive analytical account that allows a better understanding of the nature of institutional change via economic reforms, as well as the institutional path undertaken by the country in that period. In doing this, both the complexity of this type of large-scale policymaking is illustrated, and the policy legacy and trajectory of Colombia is presented. Although this is a case study and generalisations from it are limited, it can motivate similar analyses thus encouraging more political economy studies, which are historically based.

At the core of the literature on economic reforms lies the idea that reforms raise essential strategic issues. As they aim to change the status quo, the emergence of opposing interests can determine the different agents' willingness to embrace the change (Bates and Krueger 1993; Krueger 2000). Following this political economy approach, this article develops an analytic narrative in which theoretical reasoning from basic game theory and historical accounts are combined to provide a systematic and meaningful interpretation of reality (Greif 2002).

The analytic narratives approach was born from political scientists, economists and historians working together to seek more appropriate methodologies in social sciences. Instead of pursuing universal laws, it aims to grasp the richness of social interactions vis-à-vis cumulative comparative 
analysis (Bates et al. 1998). This methodology combines inductive and deductive reasoning, as it keeps the contextual specificity at a manageable level and applies theoretical devices that better structure the reasoning. Thus, historical analysis and a bounded rationality perspective provide a way to assess the multiple equilibria researchers frequently find in game theory.

I analyse the economic reforms of 1974-1978 in Colombia, looking at the strategic interactions between three collective players: Coffee, Industry and Government, taking as a point of departure simple non-cooperative games so as to identify likely coalitional agreements. The game theory model I build introduces uncertainty through nature's play. Here, the 1976 coffee boom played a major role by changing the nature of the strategic interaction between the main economic sectors. It is also assumed that Government was compromised by the adoption of full reforms but was simultaneously dependent on Coffee. Furthermore, the macroeconomic setting and tools used were biased towards Coffee's interests, meaning that Government did not have enough autonomy to coordinate both sectors neutrally.

The first hypothesis states that before the coffee boom, both sectors found it convenient to fully implement the economic reforms as economic liberalisation was viewed favourably. This interaction can be seen as an assurance game in which Government played a key role in coordinating the sectors. I discuss historical evidence and basic macroeconomics to support this view. The result of this game cannot be empirically verified for it was truncated by the coffee boom; instead it provides a base for a counterfactual assessment, which assigns a low chance to the adoption of full reforms.

The second hypothesis refers to the post-boom setting that pitted sectors against each other. This interaction can be seen as a prisoner's dilemma game. Here Industry became reluctant towards full reforms but Government sustained its commitment to them. As before, evidence in this sense is discussed. In the post-boom setting, the Nash equilibrium points to the status quo, while the only identifiable way to implement the reforms would have been through a coalition between Government and one sector. The model identifies two possible coalitions: Government-Coffee and Government-Industry. The historical outcome validates the occurrence of the Government-Coffee coalition and a half-hearted version of economic reforms. I show that the choice of this reform path finds support in Government's policymaking after the coffee boom.

This analysis provides a structural view of the reform epoch and allows us to understand the policymaking outcome reached at the end of ALM's term in government. It emphasises the underlying political economy, thereby revealing that in a strategic interaction in which the agenda setter has severely limited autonomy, the institutional change intended through economic reform will be slowed down and non-neutral unless balance in the power of the main economic sectors exists. In this scenario, what the coffee boom does, or any boom that favors one sector, is to exacerbate the 
coordination problems posed by the reforms from the outset. I develop this insight and consider alternative explanations in the final section.

The article progresses as follows. Section 2 introduces the context and contents of the reforms based on extensive work by other scholars, mainly economists and historians. In section 3 I develop the game theory model. This section uses official documents (i.e. legislative acts, government documents) and newspapers in order to underpin actors' objectives and choices. In addition, it applies the heuristic tool of decision rules to rank players' payoffs and establishes the theoretical equilibria and necessary assumptions to combine them with factual knowledge. Section 4 presents empirical evidence singling out the likely coalitional agreements and the specific reform path. I discuss factors not explicitly incorporated into the game analysis such as workers' role and reform sustainability. In section 5 I make concluding remarks. Supportive material such as the legislative chronology and proofs of equilibria are included in the appendix.

\section{INTERNATIONAL AND DOMESTIC CONTEXT}

Two major situations were present throughout the region. First, the Cold War demanded unambiguous political alignments from third world countries. Many countries in Latin America saw how military regimes took over governments with the goal of fighting communist threats. In Colombia, although there was no dictatorship, civilian governments also received this help to fight against the existing communist insurgency. However, the cooperation between Latin American governments and the United States raised internal opposition and was seen as a threat to sovereignty. This sentiment was reinforced after the military coup in Chile in 1973 when the United States was involved with the fall of Allende's socialist government. Second, the economic nationalism in the region had been rooted since the Second World War as a response to the limited trade opportunities the region had with developed countries (Bulmer-Thomas 1994, p. 263). During the 1960s the trade protection of developed countries to their agricultural and manufactured goods led Latin America to deem regional trade integration as the opportunity to give new life to industrialisation.

These two facts, the tense political relationship with the United States as well as economic nationalism, shaped Latin America's attitude towards the global market in the 1970s. On one hand, the region needed to improve its trade balance and foreign investment, but on the other hand, it sought to protect its industrial base and defend its sovereignty. These objectives required careful governmental actions so as to serve national economic interests, comply with international order and control internal political contentions.

In 1970, Colombian per capita income ranked fourteen among the twenty Latin American countries. During the 1960s, the country had an annual 
FIGURE 1

REAL ANNUAL GROWTH RATE

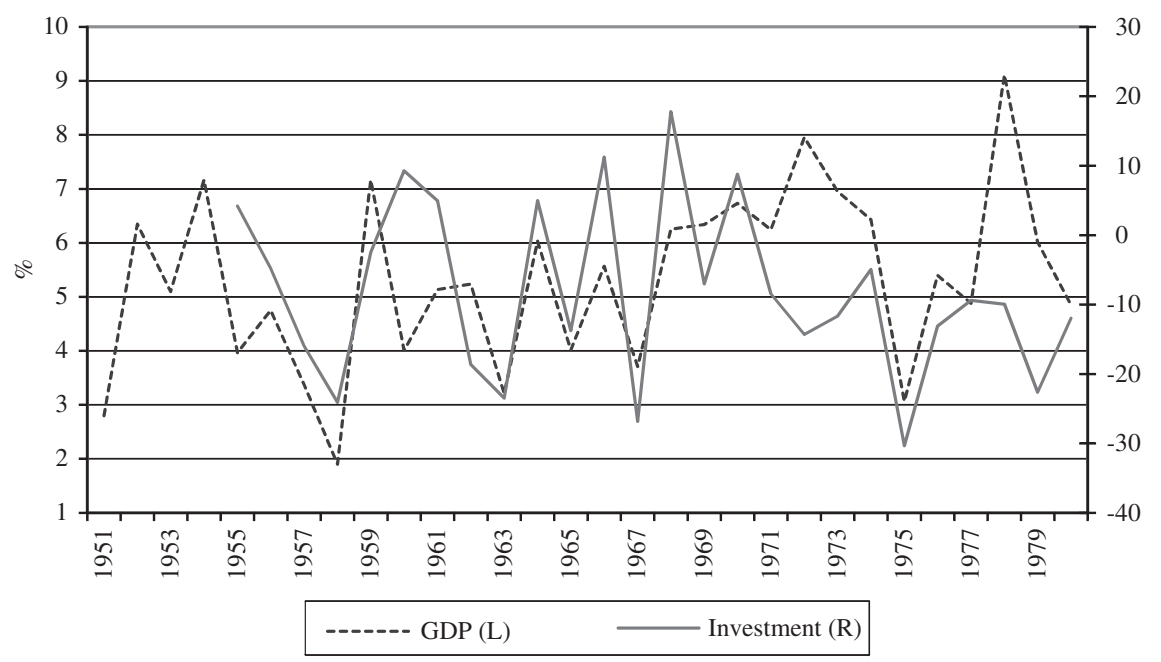

Sources: GRECO (2002) and Barrios et al. (1993).

growth rate of 5.2 per cent - which was the regional average - thus reflecting the advance of industrialisation (Bulmer-Thomas 1994, p. 309). The agricultural sector produced 25 per cent of the total GDP while industry accounted for 21 per cent. Exports accounted for 14 per cent of the GDP, with coffee being the main product, contributing $\sim 65$ per cent of the country's total exports (World Bank 2003). However, fluctuations in the international coffee market induced a cyclical character in the economy (Figure 1).

\subsection{The Economic Policy Regime}

A visible role in the international coffee market and a state-led developmental strategy shaped the economy around 1970. Since the Second World War, inward-looking development had become consolidated through the ISI model. Under this model the country expanded its industrial base by increasing trade barriers and regulating capital markets so as to provide favourable conditions for domestic industrial firms. The model operated through multiple trade tariffs and exchange rates, import quotas and licences, differential taxes, banking legislation and investment regulation, among other instruments.

Coffee was the main provider of foreign currency, but coffee prices fluctuated according to the swings of the international market bringing 
instability. First, the provision of international reserves was irregular, restricting capital goods imports. Second, the exchange rate fluctuated significantly, hindering the control of inflation and the balance of payments. Yet, the previous decades to 1970 were a period for learning how to deal with the external cycles. The crawling peg regimen adopted in 1967 gave stability to the exchange rate and reduced the volatility of inflation ${ }^{1}$.

By 1970, the growth achieved by substituting non-durable and some durable consumer goods had come to an end (Grupo de estudios del crecimiento económico colombiano (GRECO) 2002). For politicians such as ALM, the manufacturing sector lacked competitiveness in terms of price and quality partly because of the protection from international competition and price distortions (Gómez 1978). The trade barriers and capital market restrictions at this stage began to be seen as major obstacles to further industrialisation, manufactured exports and sustained economic growth. These policies were seen as responsible for the macroeconomic instability, which was perceived through volatile inflation, fiscal deficits and recurrent balance-of-payment problems.

Despite the crawling peg system, major inflationary threats were still caused by the interweaving of fiscal and monetary policies amid a policy regime prone to developmental credit. Such a regime included international credits borrowed by the government at the beginning of the 1970s, not only for public expenditure on infrastructure but also for private firms, mixed companies and state-owned enterprises. Soft loans for private firms also provided central incentives to private investment (Bulmer-Thomas 1994, p. 350). Table 1 summarises the macroeconomic policy regime in the country around 1970.

\subsection{The Political Scenario}

ALM won the presidential elections based on wide support from labour and capital accrued by offering a political and economic openness. He had led the Movimiento Revolucionario Liberal, the extremist wing of the liberal party, which criticised the lack of democracy brought by the coalitional government (Frente Nacional) that had ruled since 1958. He declared himself as leading a left-centre government, thereby receiving as many votes from privileged classes as from popular sectors (Gómez 1978; Pécaut 1988).

The dual aperture ALM promised certainly found fertile terrain. The alliance between liberals and conservatives, though useful as a solution to the violence unleashed after 1950, had modest success in addressing social demands. The Frente Nacional followed a moderate political line, far from

1 The crawling peg was a system of small but daily increases in the nominal exchange rate and a foreign exchange market controlled by the government. To some degree it lessened the transmission channel between external shocks and the domestic economy (Kalmanovitz 1997). 
TABLE 1

THE ECONOMIC POLICY REGIME IN 1970 COLOMBIA

\begin{tabular}{|c|c|}
\hline Policy instruments & Characteristics \\
\hline \multicolumn{2}{|l|}{ Fiscal } \\
\hline Fiscal balance & Deficit, expansive spending in SOEs and territorial entities \\
\hline Taxation & Low direct taxation, heavy reliance on indirect taxes (VAT) \\
\hline Domestic debt & Shallow internal capital market for public debt \\
\hline External debt & Dependency. Loans contracted in 1970/1972 \\
\hline \multicolumn{2}{|l|}{ Monetary } \\
\hline M1 & $\begin{array}{l}\text { Expansive. The monetary board include ministers of } \\
\text { finance, agriculture, development and planning that } \\
\text { favored intervention and economic stabilisation }\end{array}$ \\
\hline Inflation & Volatile. Dependent on fiscal decisions \\
\hline Interest rate & $\begin{array}{l}\text { Differential rates according to economic activity and } \\
\text { forced investments }\end{array}$ \\
\hline Developmental credit & Monetary policy and credit regulation were tied \\
\hline \multicolumn{2}{|l|}{ External } \\
\hline Crawling peg & $\begin{array}{l}\text { Semi-fixed exchange rate (continuous micro } \\
\text { devaluations), under pressures from the export sector }\end{array}$ \\
\hline Trade protection & $\begin{array}{l}\text { Tariff and quantitative protection to agriculture and } \\
\text { main industrial sectors }\end{array}$ \\
\hline Capital flows & Tight financial controls and shallow capital market for firms \\
\hline
\end{tabular}

Note: SOEs: state-owned enterprises.

Sources: Garay (1998), Junguito and Rincon (2007) and Sanchez et al. (2007).

the neoliberal or socialist extremes that severely limited the scope of economic and political reforms (Silva 1989; Hartlyn 1993). As a result, little advance was accomplished regarding land and tax reforms.

However, Colombian governments rested on a small state autonomy vis-à-vis the main interest groups. Historically, the state developed under tight fiscal constraints and its intervention was kept at a minimum level by a private sector pragmatically oriented to markets (Bejarano 2011; Saenz 2002). After 1950, a corporatist nature of the state developed when economic intervention became more pronounced and several associations of producers thrived in order to channel their demands (Nelson et al. 1971). By 1970 there 
were eighty one associations of producers; however, the most important associations amounted to no more than five, representing coffee and agricultural sectors, industry, commerce and banking. Leaders from all these organisations were appointed to official positions as a mechanism to reach consensual policies ${ }^{2}$.

Advancing collective objectives would require extraordinary mechanisms to legislate so as to concede broad faculties to the executive. Nonetheless, once these special periods ended, the measures could be overturned. Pécaut (1988, pp. 247-326) points out the high number of exceptional legislative procedures during ALM's government as a signal of the state's weakness (i.e. the economic emergency (EE) in 1974, the state of siege in 1975).

Certainly, political openness was a delicate matter to address for there were deleterious elements in the environment: a growing communist insurgency, a powerful association of peasants (Asociación Nacional de Campesinos) asking for land reform, strong labour unions and civil discontentment due to rural and urban poverty, unemployment, the low quality of public utilities and an inefficient and corrupt public administration.

Nonetheless, the 1970s were a period of management innovations in the Colombian state. New formal institutions and technocrats were incorporated during ALM's government, which displayed an intense diplomatic activity. Outstanding economists such as Miguel Urrutia, Ph.D. at Berkeley, led the technocracy while international missions such as Musgrave's focused on fiscal reform (Berry et al. 1980). Under this influence, ALM's campaign and the $1^{\text {st }}$ year of his government included widely known speeches and legislative actions whose main purpose was to persuade economic groups about the benefits of a Hayekian conception of the state and the importance of consensual price and income policies.

\subsection{The Scope of Economic Reforms}

ALM questioned the ISI strategy by pointing out its shortcomings and highlighting the fact that only by encouraging market mechanisms would economic performance improve and trade opportunities increase. Macroeconomic stability, regional trade integration and financial liberalisation were the means to stimulate capital accumulation and exports.

2 Urrutia (1983, p. 27) finds that the main associations in the 1960s and 1970s were: ANDI (Asociación Nacional de Industriales) for industry; FEDECAFE (Federacion Nacional de Cafeteros) for Coffee; SAC (Sociedad de Agricultores de Colombia) for rural landowners and producers; FENALCO (Federación Nacional de Comerciantes) for commerce; ASOBANCARIA (Asociación Bancaria) for banks and ANIF (Asociación Nacional de Instituciones Financieras) for other financial institutions. Ocampo (1996, p. 320) stresses that a network of official institutions such as councils, commissions and directed boards of decentralised state organisations relied on the participation of these associations' members. In 1981, it was estimated that 54 per cent of the officials working with state organisations were representatives of the private sector. 
TABLE 2

GOALS OF ECONOMIC REFORMS IN 1974 COLOMBIA

\begin{tabular}{|l|l|l|}
\hline Component & \multicolumn{1}{|c|}{ Policy target } & \multicolumn{1}{c|}{ Goal } \\
\hline Stabilisation & Fiscal balance & Surplus \\
\cline { 2 - 3 } $\begin{array}{c}\text { Structural } \\
\text { adjustment }\end{array}$ & Inflation & Lower and stable \\
\cline { 2 - 3 } & Tranancial liberalisation & $\begin{array}{l}\text { Competitive interest rates and } \\
\text { increased capital flows }\end{array}$ \\
\cline { 2 - 3 } & Taxes & $\begin{array}{l}\text { Reduction in tariffs and restrictions, } \\
\text { Andean Pact (trade agreement) }\end{array}$ \\
\cline { 2 - 3 } & $\begin{array}{l}\text { Price distortions (control } \\
\text { prices, subsidies, tax } \\
\text { exemptions) }\end{array}$ & $\begin{array}{l}\text { Reduction and elimination of most } \\
\text { controls }\end{array}$ \\
\cline { 2 - 3 } & \begin{tabular}{l} 
Direct state investment \\
\cline { 2 - 3 }
\end{tabular} & $\begin{array}{l}\text { Diminish it, open SOEs to private } \\
\text { initiative }\end{array}$ \\
\cline { 2 - 3 } & State bureaucracy & Downsising \\
\hline
\end{tabular}

Note: SOEs: state-owned enterprises.

Sources: López (1975) and Gómez (1978).

The way to achieve higher national income would be paved to expand economic progress and address social demands. By increasing direct tax revenues and reducing the exemptions and subsidies granted to private capital, fiscal deficits would be eliminated and competitiveness would be encouraged (Gómez 1978, pp. 90-94).

The reformist rhetoric was appealing in a moment when foreign capital inflow was promising; between 1968 and 1974, the country experienced a boom in manufactured exports and foreign investment (Garay 1998). The economic sectors expressed their enthusiasm for participating in the expansion of international markets and saw inflation volatility and fiscal deficits as undesirable features, whereas financial and trade liberalisation were deemed as necessary (Kalmanovitz 1997, p. 452; Bejarano 1985, p. 127).

Based on ALM's discourses and government plans, I summarised the reform proposals and show them in Table 2. Two components structure the reform package: macroeconomic stabilisation and structural adjustment. The first includes targets on inflation and budget deficit, and the second comprehends measures redefining state intervention and market incentives.

In ALM's view, bringing inflation down was not only a matter of monetary expansion but also of excessive subsidies and lack of market competition (Gómez 1978, p. 90). Likewise, by rationalising public spending, monetary 
control would be tight. As the exchange rate was the object of reform in 1967, this policy instrument was not under revision despite the view of economists such as Nelson et al. (1971) who sustained that the exchange rate tended to overvaluation thereby hampering manufacture exports.

As for the structural component, financial liberalisation had already been approved by the previous government, just before ALM took office. Consequently, his government found wide support from the beginning, resulting in no controversy over their adoption but rather their implementation. Nonetheless, the reform did not openly attack the developmental credit system; instead it tried to structure the system to reduce contradictions with monetary policy. Hence, the goal was to harmonise monetary discipline with an increase in financial freedom (Bejarano 1985, p. 135; Cabrera 1980, 1982).

As the trade reform hinged decisively on regional agreements such as the Acuerdo de Cartagena, or Andean Pact, the other policy targets of the structural adjustment such as direct taxation, price controls and direct state investment turned out to be the most controversial from the outset.

The plausibility of the reforms depended on ALM's ability to reach agreements with the interest groups. This amounts to a strategic interaction between key actors where initial choices are about the degree of compromise with the reforms. For analytical purposes, only two levels of commitment are distinguished: a strong commitment where reforms are fully pursued, and a low commitment in which players undertake soft or half-hearted reforms to reduce the costs associated with the change (i.e. firm subsidies decrease but selectively and marginally).

\section{STRATEGIC INTERACTIONS BETWEEN GOVERNMENT, COFFEE AND INDUSTRY}

The adoption of economic reforms can be seen as a game with three players: Government (G) and two economic sectors, Coffee (Cs) and Industry (I). Seeing a sector as a collective actor is a simplification. As usual, a parsimonious game analysis comes at the expense of not explicitly including other potential players such as the working class and the commerce or financial sector, although their role is included in the narrative.

In this game Government has two pure strategies: to commit to full reforms (F) or to commit to half reforms $(\mathrm{H})$. Coffee and Industry have two pure strategies: to commit to the reforms proposed by Government, that is to cooperate (C), or to reject them, that is to defect (D). The game is simultaneous with complete but imperfect information for the possibility of a coffee boom introduces uncertainty into the game. Hence, the game starts with a move of nature $(\mathrm{N})$, which decides on the coffee price: it could be either average or high. The game is represented in Figure 2. 
FIGURE 2

THE GAME TREE

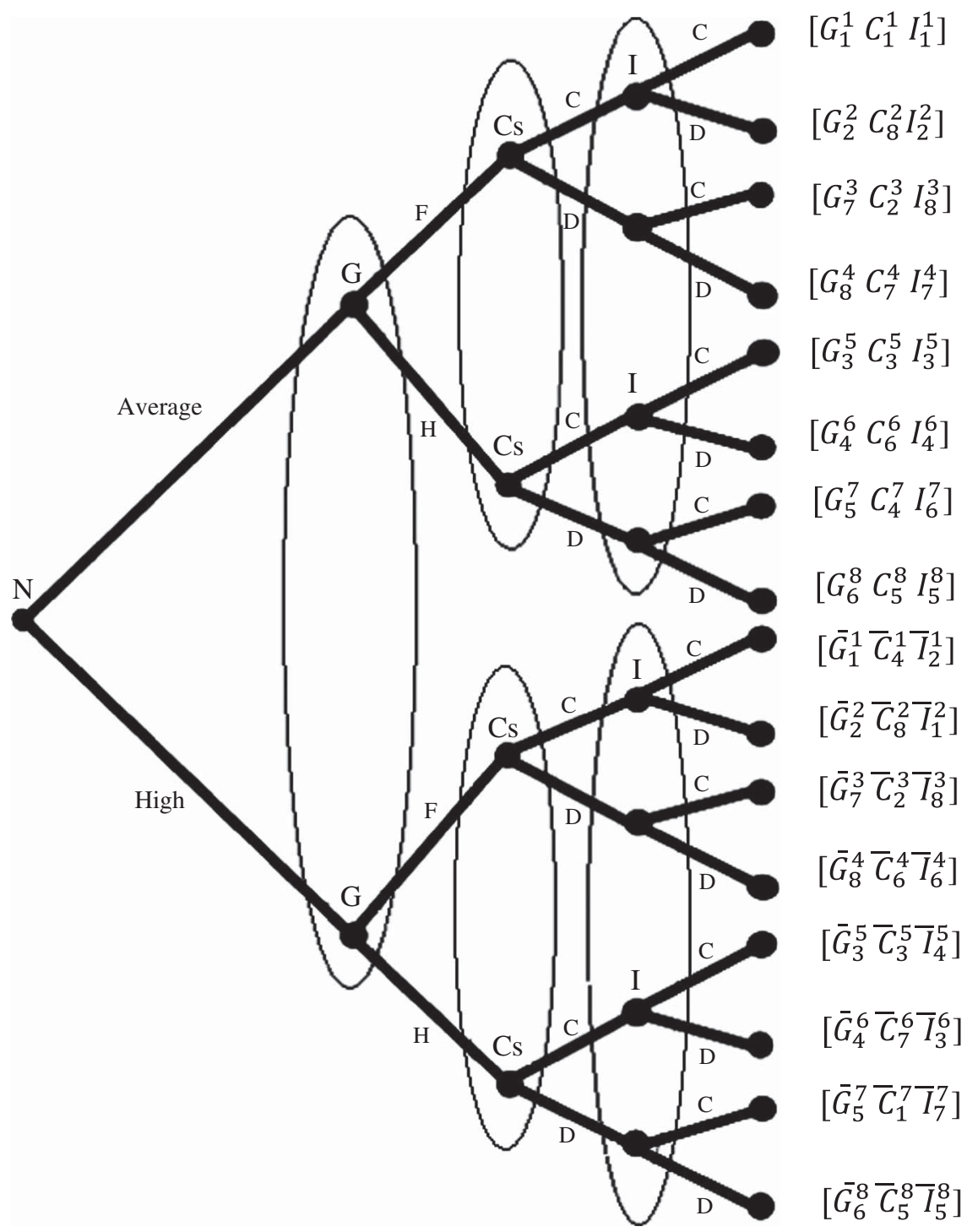

Nature's move brings two possible sub-games: one when the prices are average and the other when they are high. As the players do not have perfect information, they may assign probabilities to these sub-games. Despite the fact that the export cycles due to fluctuations of international coffee prices 
were a main characteristic of the Colombian economy, the 1976 coffee boom was an unexpectedly large shock. In terms of the game, it means that players cannot form mixed strategies to protect themselves. Instead, players must play at either decision node once they are able to update their informational set after nature's move.

$S_{k}$ denotes the set of strategies of player $k$, where $k=\{\mathrm{G}, \mathrm{Cs}, \mathrm{I}\}$. Each strategy indicates the combination of strategies chosen by G, Cs and I, respectively. For instance, the strategy FCC denotes that G commits to full reforms and Cs and I choose to cooperate. Thus, $S_{k}=\{F C C, F C D, F D C, F D D$, $H C C, H C D, H D C, H D D\}$. These strategies are enumerated in this order with an upper subscript from 1 to 8 for short identification, and re-expressed as $S_{k}=\left\{k^{1}, k^{2}, \ldots, k^{8}\right\}$. The associated function of payoffs is denoted by $U_{k}=\left\{k_{r}^{s}\right\}$, where $s=(1, \ldots, 8)$ indicates the strategy order, and the lower subscript $r=(1, \ldots, 8)$ denotes the ranking each player assigns to each strategy, from high to low.

Full reforms are attained through the strategy FCC, while the status quo is kept through any strategy in which both sectors defect (FDD, HDD). Half reforms are reached either when $\mathrm{G}$ chooses half reforms and both sectors cooperate (HCC), or when at least one sector cooperates independently of G's choice (FCD, HCD, FDC, HDC).

The payoff function is specified in a ranking that must reflect how the player evaluates each strategy's net benefits. The first step to approximate players' valuations is to define functions of expected net gains. This is done through general functions of expected profits using basic macroeconomic reasoning. The second step is to translate these functions into ordinal payoffs through rules of decisions. A rule of decision indicates how a player ranks a set of discrete strategies and is based on a heuristic interpretation of a player's interests. The heuristic interpretation possesses a historical and a theoretical component that work interactively so as to produce a coherent reading of players' behaviour (Mares 1988).

\subsection{Government}

The basic preference of any government is to stay in office and, in a democratic setting, increase its party's political capital through policy responsiveness. The expected gains function of Government can be expressed as $E\left(V_{\mathrm{G}}\right)=f\left[\alpha_{1} E\left(V_{\mathrm{Cs}}\right), \alpha_{2} E\left(V_{\mathrm{I}}\right), \alpha_{3} E\left(V_{\mathrm{W}}\right)\right]$. Here, $E\left(V_{\mathrm{Cs}}\right)$ and $E\left(V_{\mathrm{I}}\right)$ represent the expected value of Coffee's and Industry's profits, respectively, reflecting that Government's political capital depends on the economic performance of these sectors, while $E\left(V_{\mathrm{W}}\right)$ stands for the expected workers' income signalling this group as an electoral force for the ruling political party. The constant $\alpha$ represents the weight each sector has in Government's interests. Here, $\sum_{i} \propto=1$ and $\alpha_{1}>\alpha_{2}>\alpha_{3}$, meaning that Coffee brings the higher political support. 
This picture is grounded in the historical characteristics of ALM's government and the Colombian state. After the Great Depression, coffee producers became a powerful group that dominated the macroeconomic policy and co-legislated its own regulation policies. Indeed this sector structured the Colombian state through its affective collective action (Palacios 1983, p. 504; Mares 1993).

The National Federation of Coffee Producers (Federación Nacional de Cafeteros, FNC), a sui generis institution of mixed character between an interest group and a decentralised state agency, set the channel for this high leverage. Many managers of the FNC served as minister of finance, revealing this post as that of an intermediary between this interest group and the state (Palacios 1983, p. 522). Furthermore, with the National Coffee Fund, established in 1940 to manage public revenues from special coffee taxes, the FNC acquired significant financial power. In terms of institutional structure, the FNC was a semi-state organism with autonomy and therefore isolated from the political class and parliament (Ocampo 1987, p. 288).

Not only was the institutional state structure prone to prioritise the coffee sector's needs, but also ALM found himself tied to the sector's interests. He came from one of the elite's prominent families, whose fortune was associated with the coffee business and whose importance in Colombian political life had been long established. However, ALM targeted the interests of the growing mass of urban workers, following his father's footsteps for Alfonso López Pumajero was a liberal leader in the 1940s recognised for his achievements in land reform and labour-oriented legislation (Gómez 1978, p. 61). This is how ALM's government established policies favoring union activity and enacted mandatory inflationary adjustment in wages, the right to strike indefinitely and wage payments during strikes.

In regard to industry, ALM was an advocate of adjustment in the light of the comparative advantage and efficiency principles. He underlined the urgency of increasing agricultural productivity, but by means of more developmental credits that would capitalise farms on a larger scale (Pécaut 1988, p. 249). Agriculture was the key because the country was mainly agrarian. Thus, he advocated the promotion of agriculture and the purging of industry at a time when industry and agriculture contributed equally to the GDP. While agriculture went from contributing over 27 per cent of the GDP in the 1960s to 23 per cent in the 1970s, industry increased its aggregate value from 21 to 23 per cent in the same decade (GRECO 2002). Therefore,

Decision Rule for G: It prefers those strategies in which Cs cooperates over those when Cs defects. If $\mathrm{Cs}$ chooses $\mathrm{C}$, it would rather commit to full $(\mathrm{F})$ rather than to half reforms $(\mathrm{H})$ and it prefers that both sectors cooperate instead of only one. If Cs defects, it chooses $\mathrm{H}$ over $\mathrm{F}$ but it prefers that industry cooperates rather than defects. 
The payoff function associated with $S_{G}$ is given by $U_{G}=\left\{G_{1}^{1}, G_{2}^{2}, G_{7}^{3}, G_{8}^{4}, G_{3}^{5}, G_{4}^{6}, G_{5}^{7}, G_{6}^{8}\right\}^{3}$. G's decision rule indicates its preference for full reforms and given the dominance of Coffee, its greatest payoff lies in undertaking full reforms when Coffee cooperates. Otherwise, Government would try out a soft version of the reforms.

\subsection{Coffee}

This sector seeks higher profits that depend on the real value of domestic and international sales and capital and labour costs $(\mathrm{r}, \mathrm{w})$. The profits are also influenced by subsidies net of taxes $\delta_{c}$. This sector's expected profits can be seen as: $E\left(V_{\mathrm{Cs}}\right)=f\left(\frac{Q_{c} P_{c}}{P}, \frac{Q_{c}^{*} P_{c}^{*}}{P}, \delta_{c}, r, w\right)$, where $Q_{c}$ and $P_{c}$ represent domestic coffee product and price, the starred variables indicate exports and international price; $P$ and $e$ stand for the general level of prices and the nominal exchange rate.

Because of the close relationship between the National Coffee Fund and Government, the general level of prices, and by extension the real exchange rate, was substantially influenced by international coffee prices. This fact is captured by the inflation function in which the expected inflation depends on the growth of money $(\mathrm{M})$ and the gap between the current and the average international coffee prices. Thus, $E(\pi)=f\left[\Delta M, \lambda\left(P_{c}^{*}-\bar{P}_{c}^{*}\right)\right]$. The parameter $\lambda$ refers to the degree by which the fluctuations of the international prices are transmitted to the domestic economy, where $0<\lambda<1$.

By the beginning of 1970 the coffee sector showed signs of weakness. Coffee exports reduced their participation in total exports to 50 per cent reflecting changes in the world coffee market as well as in the domestic structure of production. Other domestic sectors questioned the power of the FNC in the light of conflicts over devaluation, inflation and income redistribution (Palacios 1983, p. 523; Pécaut 1988, p. 270). At the core of the debate was the high correlation between exchange rate management and international coffee prices for when the price of coffee was high (or low) the real exchange rate appreciated (or devaluated). Coffee cycles did not contribute to the development of non-coffee sectors despite the stabilisation effect of the crawling peg system (Gómez and Leibovich 1987).

It is reasonable to contend that the sector perceived ALM's reform agenda as a way to address these criticisms. Coffee would benefit from lower fiscal deficits, financial openness and trade liberalisation because the pressures on higher taxation and the capital costs would diminish. Coffee was not as sensitive to trade reform as Industry because it did not have external competitors in the domestic market and its exports hinged on a bargained share of the international market. Furthermore, the relative strength of the

3 The ranking of G's strategies can be also expressed as $\mathrm{FCC}>\mathrm{FCD}>\mathrm{HCC}>\mathrm{HCD}>\mathrm{HDC}>\mathrm{HDD}>$ FDC $>$ FDD. 
National Coffee Fund eased the financial constraints the sector may have experienced. Real devaluations were not crucial to maintain its internal competitiveness, which was based on high productivity (Ocampo 1996, p. 288). In addition, reforms did not overtly question the price controls, subsidies or tax exceptions enjoyed by Coffee.

Certainly, Coffee was particularly sensitive to tax reform as the sector had fiercely opposed discriminatory taxes on its exports. Between 1963 and 1974 the fiscal revenue from coffee exports declined from 78 to 36.2 per cent, a result of intense lobbying and the unclear methodology of adjusting taxation according to external cycles (Ocampo 1987, 275-294; Pécaut 1988, pp. 260-262). Critics pointed out the extra income the sector perceived because of the post-1967 devaluations and supported higher taxes to coffee producers. The sector argued that when a boom occurred, the subsequent real appreciation equated to a tax on coffee exports and alleged that the boost in domestic demand would distribute the extra income throughout the economy much better than any policy measure.

\subsection{Industry}

Like Coffee, Industry seeks higher profits and has a similar expected profits function but applied to industrial activity. Industry expanded from the Great Depression onwards, initially linked to agro-export activities. These industrial agents led both the industrial and coffee sector and had close objectives with no deep political and economic antagonisms (Palacios 1983, p. 506). This commonality of interests began to vanish in the 1960s when Industry advanced towards the production of complex goods, leading processes of vertical and horizontal integration.

The concentration of ownership along with new conglomerates redefined new industrial interests in the 1960s placing them closer to the financial sector than coffee producers. Yet, Industry was far from having the same cohesion and strength as Coffee so as to openly confront Coffee's interests whenever it deemed it harmful. According to Mares (1993), the support granted by governments under the ISI prevented the sector from structuring an effective collective action.

Industry production was mainly intended for domestic markets and was more capital than labour intensive. From 1950 to 1970, it advanced from the production of non-durable goods to the production of intermediate goods and, to a lesser extent, towards capital goods production. By 1974, 37 per cent of the industrial aggregate value was concentrated on non-durable goods, 49 per cent on intermediate goods and 14 per cent on capital goods (Ocampo 1996, p. 274).

At this point, Industry found it convenient to relax trade controls for it had imported 67 per cent of total imports during the 1960s. Two-thirds of 
these imports were raw materials while the rest were capital goods. The reduction in non-trade and trade barriers began sluggishly in 1970, targeting raw materials and capital goods. In 1974 sectors such as beverages, textiles, clothes, wood, shoes and plastics still had nominal trade tariffs higher than 60 per cent, whereas sectors like food, paper and chemicals had tariffs around 25 per cent on average. Taking into account non-trade tariff restrictions such as previous import licences, quantitative restrictions and money deposits, the effective protection for food, beverages, tobacco, textiles, clothes, furniture and plastics was more than 100 per cent. Among capital goods, transportation equipment had an effective protection around 80 per cent (Garay 1998, p. 320).

The viability of trade reform hinged on the expected value of industrial exports as a result of the stability of the real exchange rate, expanded international markets and export subsidies. On trade agreements, the Andean Pact promised new opportunities and meant a crucial incentive to trade liberalisation. The model to follow was textiles, a subsector that entered into a U.S.A. trade agreement in 1977.

Industry was especially sensitive to reductions in the export subsidy called Certificado de Ahorro Tributario. In September 1974, Government reduced it from 15 to 5 per cent arguing that it increased the budget deficit. As long as industrial exports were encouraged by alternative policies, this sector was willing to negotiate. Clearly, Industry's expectations of lower capital costs and higher investment inflows by means of financial liberalisation could offset the risks entailed by increased exposure to international markets ${ }^{4}$.

Judged by its initiatives, this sector was open to consider key issues during ALM's $1^{\text {st }}$ year, playing an active role in criticising the measures introduced and assessing their scope. The ANDI, along with other producers' organisations, constantly underscored the need for more aggressive strategies to overcome the financial tightness and stimulate trade. In doing so, Industry managed to reach some beneficial agreements with Government such as lower capital taxes for limited liability companies ${ }^{5}$.

The developmental strategies of preceding governments, focused on agriculture and urban building development (e.g. Currie's Plan), fed Industry's sentiment of being neglected, reinforcing its perception of incomplete industrial policies. In Industry's eyes, the promotion of industrial exports, implemented since the mid-1960s, was a broad policy that still demanded

${ }^{4}$ El Tiempo: 22 September 1974, p. 11A, 29 September 1974, p. 13A, and 1 November 1974, p. 1. ANDI, the industrial association, pointed out that CAT's reductions discouraged exports and demanded a more flexible capital market. Afterwards, ANDI and other associations proposed an alternative export plan, El Tiempo, 6 December 1974, p. 1.

5 This turned out to be one of the amendments to the fiscal reforms enacted at the beginning ALM's government. El Tiempo, 13 October 1974, p. 1. Subsequently, at the end of 1974, important industrial businessmen from Antioquia expressed their support to ALM; see El Tiempo, 19 December 1974, p. 9A and 10 March 1975, p. 6. 
actual support and complementary policies (Pécaut 1988, p. 201). In this way the 1974 reforms were intended to address Industry's claims.

\subsection{Willingness to Cooperate: from August 1974 Until December 1975}

Based on declarations of Coffee and Industry, it can be sustained that both sectors deemed ALM's economic reforms beneficial. These sectors made public their willingness for full stabilisation, favored financial deregulation, were willing to negotiate tax reform and agreed in reducing the size of the state. Although other aspects, such as eliminating some price controls and reducing all trade tariffs, remained controversial, it is reasonable to interpret that the initial support was for full reforms. From this stance, potencial disagreements between players are seen as the space for bargaining instead of radical opposition to the reforms.

Although initially there was a tense environment between private sectors and Government because of the tax reform, the 1975 oil shock and the subsequent slowdown drove Government to abandon its radical position on taxes. Private sectors were given policies and promises of relief for the sake of the economic recovery. This movement sustained associations' willingness to cooperate with Government's plans ${ }^{6}$.

On this ground, I use the assurance game to represent the interaction between Coffee and Industry so that mutual cooperation is the preferred outcome and there is no exploitation of the opponent; rather, both players prefer to follow the other's strategy. For example, if Coffee defects full reforms, then it does not benefit from Industry's commitment to full reforms insofar as Coffee understands that its commitment is also necessary for the reform to be profitable in its interest. Industry judges the situation in the same way. Thereby, one player's defection and the other player's cooperation do not lead to appealing payoffs.

The typology of payoffs for a simultaneous two-player game follows Tsebelis (1990). In a simultaneous two-person game there are four possible outcomes: reward $(\mathrm{R})$ for mutual cooperation, penalty $(\mathrm{P})$ for mutual defection, temptation $(\mathrm{T})$ when one player defects and the opponent cooperates and sucker (S) when one player cooperates and the opponent defects. In an assurance game, the order of the strategies' payoffs for both players is given by $\mathrm{R}>\mathrm{T}>\mathrm{P}>\mathrm{S}$. Thus, the decision rules for $\mathrm{Cs}$ and $\mathrm{I}$ under average coffee prices can be:

Decision Rule for Cs and I (Average coffee price): Including a superscript in the payoffs, with $\mathrm{f}$ and $\mathrm{h}$ indicating the payoff under full

6 El Tiempo, 19 December 1974, p. 9A and 20 December 1974, p. 1. In this line, Government made a soft loan to four major textile companies, El Tiempo, 6 August 1975, p. 2. Later on, these companies' payments were deferred, El Tiempo, 30 July 1976, p. 15A. 
and half reforms respectively, the payoff order for every sector is $\mathrm{R}^{\mathrm{f}}>$ $\mathrm{T}^{\mathrm{f}}>\mathrm{R}^{\mathrm{h}}>\mathrm{T}^{\mathrm{h}}>\mathrm{P}^{\mathrm{h}}>\mathrm{S}^{\mathrm{h}}>\mathrm{S}^{\mathrm{f}}>\mathrm{P}^{\mathrm{f}}$. A sector chooses the reward $(\mathrm{R})$ or the temptation ( $\mathrm{T}$ ) payoff when $\mathrm{G}$ chooses $\mathrm{F}$ over the $\mathrm{R}$ or $\mathrm{T}$ payoffs when $\mathrm{G}$ chooses H. However, it prefers the penalty $(\mathrm{P})$ or the sucker $(\mathrm{S})$ payoff when $G$ chooses $H$ rather than the $P$ or $S$ payoffs when $G$ prefers $F$.

The reward and the temptation payoffs are higher under full reforms than under half reforms because of sectors' positive perceptions of the former. In the same way, the penalty and the sucker payoff are lower under full reforms than under half reforms reflecting that when only one sector engages with full reforms, it has to endure the whole tax burden and the lower level of subsidies alone. Thus, each player recognises the benefits of full reform but is not willing to undergo the entire cost, which is heavier under the full than under the half version of reforms, on its own.

The payoff functions associated with $S_{\mathrm{Cs}}$ and $S_{\mathrm{I}}$ are, respectively: $U_{\mathrm{Cs}}=$ $\left\{C_{1}^{1}, C_{8}^{2}, C_{2}^{3}, C_{7}^{4}, C_{3}^{5}, C_{6}^{6}, C_{4}^{7}, C_{5}^{8}\right\}$ and $U_{\mathrm{I}}=\left\{I_{1}^{1}, I_{2}^{2}, I_{8}^{3}, I_{7}^{4}, I_{3}^{5}, I_{4}^{6}, I_{6}^{7}, I_{5}^{8}\right\}$.

Under average coffee prices, the other sector's exploitation is prevented by the joint movement of the expected real value of production and price inputs in the expected value functions. Since the reforms would bring down inflation and input costs and stimulate productivity, the payoffs for both sectors would evolve in the same direction. As the assurance game involves a coordination problem between sectors, the attainment of the optimal equilibrium critically depends on setting a focal point such that all players cooperate.

Government could play a critical role in solving the coordination problem by building up credibility in its commitment and establishing mechanisms to facilitate bargaining between sectors. Otherwise the outcome will be mutual defection. As this game was truncated by an international shock caused by the international coffee market (Figure 3), the outcome is not observable.

\subsection{The Coffee Boom and Sector Rivalry: from January 1976 Until August 1978}

Coffee prices skyrocketed in 1976 bringing about an unexpected situation. First, the international agreement between major producers and the United States, the main consumer, had not established market shares since 1972, an aspect that was not redefined until 1980. Second, Brazil, the biggest producer, underwent severe frosts at the end of 1975, dramatically decreasing the world supply (Ocampo 1996, p. 316). As a result, the national supply of coffee, unconstrained by the international market, could expand and capture a great deal of the extraordinary increase in international prices.

Once the boom had been acknowledged, players updated their informational sets and reassessed their strategies. However, this update occurred 
FIGURE 3

COFFEE PRICE FOR COLOMBIAN VARIETY

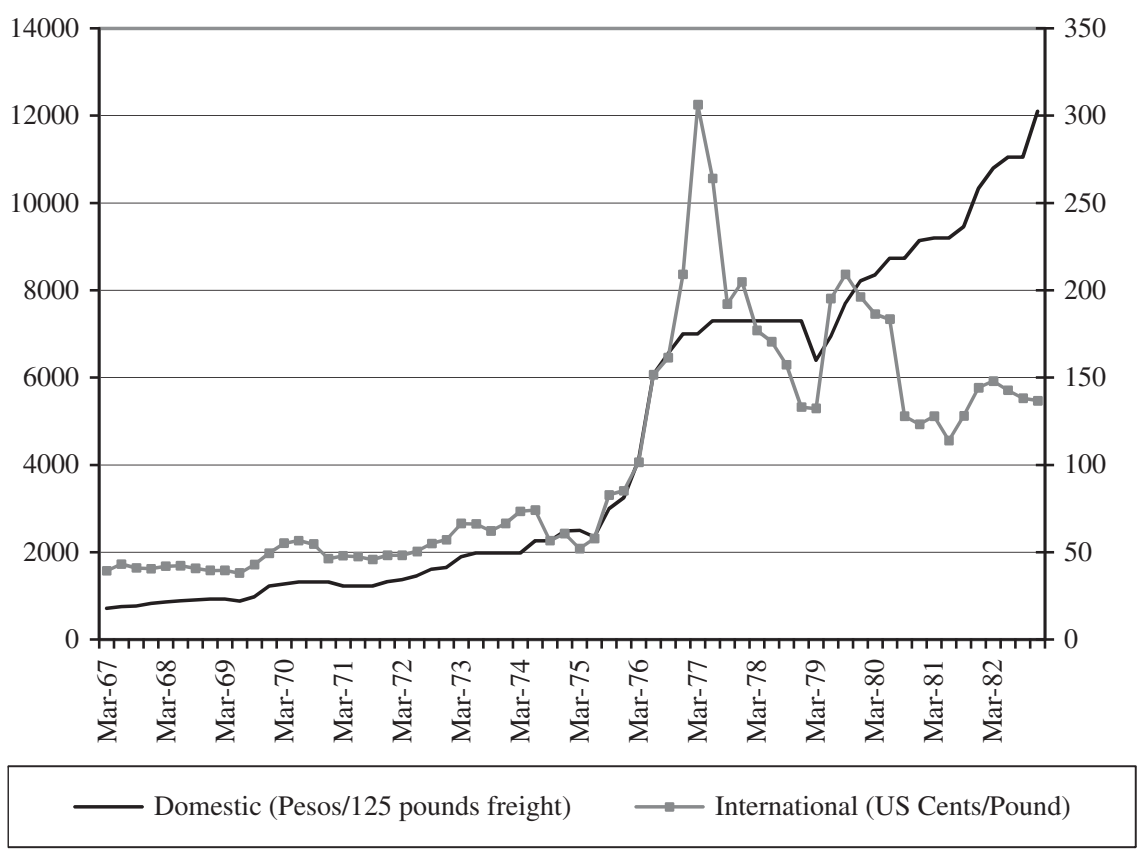

Source: FEDECAFE.

differently in Government and sectors. From late January 1976 until September 1977 ALM's government paralyzed its reform activity and focused on managing the boom which, in Government's view, was as totally unexpected as the way in which it disrupted economic policymaking ${ }^{7}$.

The truth was that Government never considered, neither ex-ante nor ex-post, the incompatibility between economic reforms and a coffee boom. Excess of confidence in the extant macroeconomic tools for coffee regulation and the unusual size of the shock might explain Government's oversight. In terms of the game, Government's paralysis meant that it did not update its payoffs and ranked them differently once the new scenario emerged. Alternatively, this can be interpreted as Government's inability to respond to the shock. Figure 2 indicates this feature by joining the decision nodes of G.

Under high coffee prices, the interaction between players changes because some of the variables in the expected value functions have opposite effects on Coffee and Industry. Overall, the bone of contention would be

${ }^{7}$ El Tiempo, 21 July, 1977, p. 6. 
inflation, mainly driven by coffee prices, and whose management would reduce the expected real value of industrial output while it would increase the expected value of coffee production. Both sectors, aware of their relative strength could recognise that the coffee boom would lead the economy towards the Dutch disease. This would stimulate the nominal demand for non-tradable production and discourage the supply of non-coffee tradable sectors in the short-run. Even though neither Coffee nor Industry could foresee the extent of the coffee boom, they could certainly identify its effects.

Full stabilisation would bring about higher costs for Coffee, stemming from lower inflation and less expansionary fiscal policy; under tight monetary policy, much of the extraordinary profits from exports could not get into the economy and coffee businessmen would have to wait to realise their profits in domestic currency. Moreover, disciplining fiscal policies would put more pressure on Coffee's income whereby its short-run profits would diminish. To Industry, full reforms were still appealing because the control of inflation would guarantee a stable real exchange rate while financial liberalisation would provide the capital that Industry had longed for. Nonetheless, this positive stance critically depended on broader opportunities in the international market.

A prisoner's dilemma game captures this interaction fairly because the opposition of interests leads to the opponent's exploitation. Taking into account the reform components (Table 2), defection for Coffee signifies it does not commit to full but to half stabilisation. Nonetheless, Coffee might benefit from Industry's commitment to full structural adjustment, especially in view of its attachment to protection. Industry's acceptance of full reforms would break down practices that burdened the fiscal budget and lessened market competition.

To Industry defection means to commit not to full but to half structural adjustment. In addition, this player is aware of potential benefits from Coffee's commitment to full stabilisation. Given Coffee's main role in driving macroeconomic variables, low inflation and fiscal discipline would bring stability that in turn would stimulate economic growth. In consequence, each sector prefers to defect in order to protect itself from exploitation, no matter what the other does. The order of payoff in a prisoner's dilemma following Tsebelis (1990) is T $>\mathrm{R}>\mathrm{P}>\mathrm{S}$. Thus, the decision rules for Cs and I under high coffee prices can be stated as:

Decision Rule for Cs (High coffee price): The preference order of payoffs is $T^{h}>T^{f}>R^{h}>R^{\mathrm{f}}>P^{h}>P^{f}>S^{h}>S^{f}$. Then, Cs prefers the temptation ( $\mathrm{T}$ ) payoff regardless of whether $\mathrm{G}$ chooses $\mathrm{F}$ or $\mathrm{H}$, although it prefers the payoff obtained under $\mathrm{H}$. In the same way, after $\mathrm{T}$, it prefers $\mathrm{R}$ whether $\mathrm{G}$ chooses $\mathrm{F}$ or $\mathrm{H}$, although it prefers that obtained under $\mathrm{H}$. After R, it prefers $\mathrm{P}$ regardless of whether $\mathrm{G}$ chooses $\mathrm{F}$ or $\mathrm{H}$, though it prefers that obtained under $\mathrm{H}$. After $\mathrm{P}$, it prefers the payoff it gets under $\mathrm{H}$. 
Under high coffee prices, Coffee has a strong incentive to defect and has a preference for the strategies where Government chooses half reform. The function of payoffs for $\bar{S}_{\mathrm{Cs}}$ is: $\bar{U}_{\mathrm{Cs}}=\left\{\bar{C}_{4}^{1}, \bar{C}_{8}^{2}, \bar{C}_{2}^{3}, \bar{C}_{6}^{4}, \bar{C}_{3,}^{5}, \bar{C}_{7}^{6}, \bar{C}_{1}^{7}, \bar{C}_{5}^{8}\right\}$.

Decision Rule for I (High coffee price): The preference order of payoffs is $\mathrm{T}^{\mathrm{f}}>\mathrm{R}^{\mathrm{f}}>\mathrm{T}^{\mathrm{h}}>\mathrm{R}^{\mathrm{h}}>\mathrm{P}^{\mathrm{h}}>\mathrm{P}^{\mathrm{f}}>\mathrm{S}^{\mathrm{h}}>\mathrm{S}^{\mathrm{f}}$. Industry prefers the temptation $(\mathrm{T})$ and the reward (R) payoff when $G$ chooses $F$ rather than the $T$ and $R$ payoffs obtained when $\mathrm{G}$ chooses $\mathrm{H}$. However, it prefers the penalty $(\mathrm{P})$ payoff if $\mathrm{G}$ chooses either $\mathrm{H}$ or $\mathrm{F}$ rather than the sucker (S) payoff. In addition Industry prefers the $\mathrm{P}$ and the $\mathrm{S}$ payoff under $\mathrm{H}$ rather than under $\mathrm{F}$.

This rule is not as straightforward as Coffee's due to Industry's weaker stance. Industry prefers full to half reforms but it would choose to defect over to cooperate. It is better off whenever Coffee cooperates and Government undertakes full reform. However, when Coffee defects, Industry finds half reform more advantageous since the payoffs are lower when full reform is supported by only one sector; Industry understands that full reform would turn out much more costly when it supports it alone. The function of payoffs for $\bar{S}_{I}$ is: $\bar{U}_{\mathrm{I}}=\left\{\bar{I}_{2}^{1}, \bar{I}_{1}^{2}, \bar{I}_{8}^{3}, \bar{I}_{6}^{4}, \bar{I}_{4}^{5}, \bar{I}_{3}^{6}, \bar{I}_{7}^{7}, \bar{I}_{5}^{8}\right\}$.

\subsection{The Game Solutions: Non-Cooperative and Coalitional Agreements}

The models' predictions correspond to equilibria determined by applying two standard solutions: Nash equilibrium or non-cooperative equilibrium and rational coalitions. Coalitions are frequently observed in collective choice situations particularly in reform endeavours. A coalition may arise when subsets of players have the possibility of cooperating and choosing joint strategies in order to share higher payoffs that non-cooperative strategies would not bring.

The prisoner's dilemma and the assurance game are essential games because players gain more by colluding than by acting individually. In each game there are seven possible coalitions. Three are the one-element coalitions that correspond to the individual safety level and coincide with the Nash equilibrium. Three are the bilateral combinations and finally there is the grand coalition including all players. The space of strategies for the coalition formed by $\mathrm{G}$ and one sector, either $\mathrm{C}_{\mathrm{s}}$ or $\mathrm{I}$, the coalition $\mathrm{C}_{\mathrm{s}}-\mathrm{I}$, and the grand coalition are respectively: $\quad S_{\mathrm{G}_{-} \mathrm{C}_{\mathrm{s}} \wedge \mathrm{I}}=\{F C, F D, H C, H D\}, \quad S_{\mathrm{C}_{\mathrm{s}} \mathrm{I}}=\{C C, C D, D C, D D\}$, $S_{\mathrm{G}-\mathrm{C}_{\mathrm{s}} \mathrm{I}}=\{F C C, F C D, F D C, F D D, H C C, H C D, H D C, H D D\}$. The payoff associated with each strategy, or coalition value, is the union of individual payoffs determined by the non-cooperative game. It is assumed that these values are transferable so that players can make side-payments.

${ }^{8}$ A coalition is defined by the set of players that conforms it, and its characteristic function that indicates the minimum payoff the coalition can guarantee independently of what the players who are not in the coalition choose (Cochinard 2002, p. 90). 
TABLE 3

GAME EQUILIBRIA

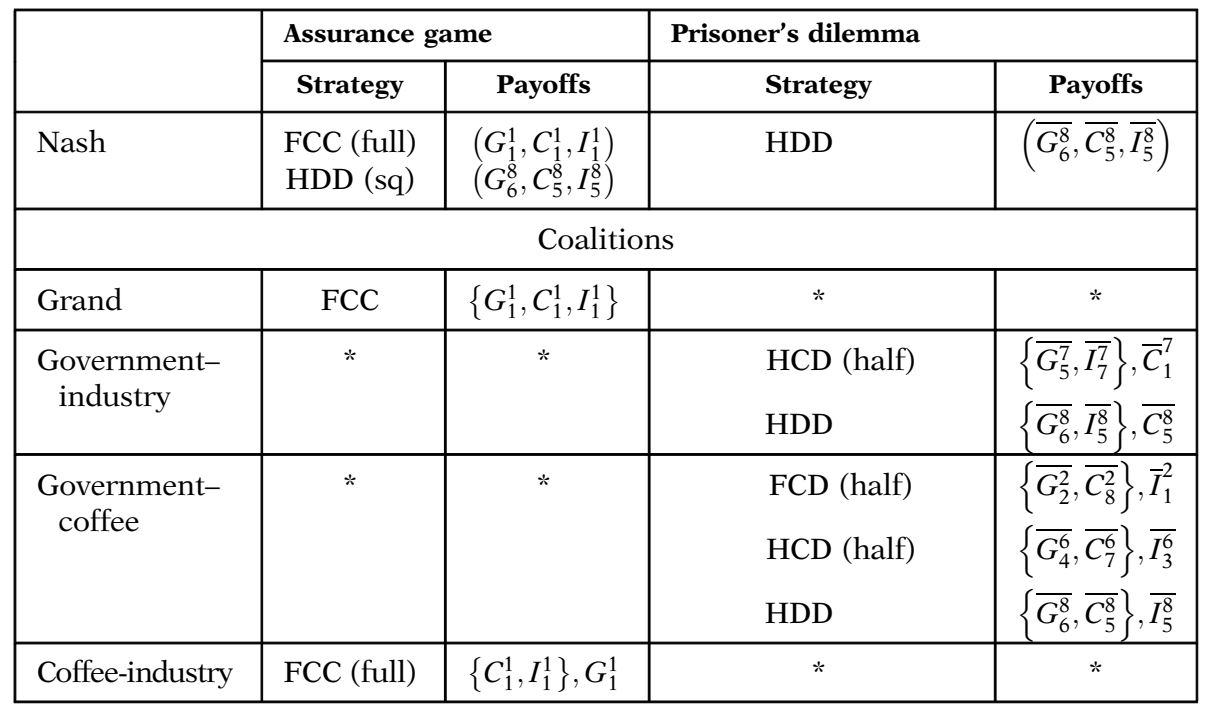

Note: sq: status quo, half/full reforms.

*Undetermined.

A dominant strategy is defined by unanimity rule whereby all individual payoffs' sub-indices must be lower than those of the dominated strategy. This means that all players assign a higher rank to the dominant strategy. In this context, the coalitional equilibrium is undetermined when it is not possible to eliminate at least two dominated strategies. In these cases the coalition would randomise its strategy between dominant strategies, but conjectures about this choice with ordinal payoffs are precarious. Table 3 summarises the game equilibria (proofs in the appendix).

Table 3 contains the identifiable strategies each individual and coalition could rationally play. Two assumptions are required to arrive at additional insights. First, the identifiable strategies are substantially more likely than the non-identifiable, basically because players can perceive them more straightforwardly than the others. This comes from the fact that the heuristic applied to the decision rules is simple but still rational reflecting limited rationality in players. Second, these strategies can be assessed by using historical characteristics of the strategic scenario.

The assurance game displays two Nash equilibria, either full reforms or the status quo in which the chosen equilibrium hinges on Government's coordination as agenda setter. In coalitional form the optimal strategy is played either by the grand coalition or by the sectors' coalition. These possibilities are assessed in the next section. 
The Nash equilibrium out of the prisoner's dilemma is total rejection of half reforms and the return to the status quo. The prediction is inaccurate because the factual outcome is better addressed as a scenario of half reforms whereby certain reform policies were embraced. Hence, two identifiable coalitions could fit the actual outcome: Government-Industry and Government-Coffee. Let us go back to historical facts.

\section{ASSESSING RESULTS: COALITIONS AND THE REFORM PATH}

\subsection{Government's Coordination Ability}

Low state autonomy was characteristic of Colombian governments and ALM was well aware of this. Previous governments' failures in bargaining with capital owners and workers had drawn a clear picture of the pitfalls. Thus, Government created a committee called Comisión Tripartita, or tripartite commission, on 14 September 1974, in which the interests of Government, producers and workers would be neutrally represented to discuss income and price control policies. This commission was ALM's attempt to coordinate economic agents on crucial reform points.

However, the honeymoon of the concerted economy was unexpectedly diluted by the declaration of the EE on 17 September; about 1 month after ALM took office. The EE allowed the president to legislate for 45 days without Congress' ratification. The executive used this mechanism arguing that the budget deficit and inflation were extremely high and required immediate action. Having identified the key role of tax reform and the failures of past experiences, Government chose to legislate on its own rather than negotiate with the tripartite commission. Although the justification was to intensify the fight against inflation to preserve incomes and wages, EE's legislative activity focused on tax and administrative reform. The former included a reduction in tax cuts, increases in tariffs according to income level as well as increases in taxes on land, luxury items and occasional profits. The administrative reform provided wide faculties to modify or suppress decentralised institutions ${ }^{9}$.

At the outset, the EE was welcomed by the sectors as part of the process of macroeconomic stabilisation. It was seen as a way of isolating Government's decisions from bargaining on prices and wages with firms' owners and workers. However, once the measures targeted the tax structure, resistance from associations came into play. The main economic sectors rejected them and effectively invested resources so as to change the emergency legislature once the special period ended ${ }^{10}$.

9 Diario Oficial \#34170, legislative decree 1970, 17 September 1974, p. 645.

10 El Tiempo, 15 September 1974, p.1 and 3 October 1974, p. 1 and 6A. The 1974 tax reform is cogently portrayed by Urrutia (1983, pp. 175-232). See also Pécaut (1988, p. 253). 
The next government would have to concede much more on tax issues as the tax structure that emerged in the 1980s testifies. Such a structure reflects the counter-reforms of 1977 and 1979 (Garay 1998, pp. 298-300). Government's poor coordinating capacity was evident from the failure of the tripartite commission and the use of the EE. Such a strategy of isolation based on temporary legislative mechanisms and technocratic authority was overtly ineffective thus reinforcing past privileges and entangling tax legislation.

In this light, even in this non-booming scenario, a grand coalition was unlikely. A coalition between sectors, though possible, would have established a historically unusual situation whereby institutional change affecting the structure of the state is mainly led by constituents instead of rulers ${ }^{11}$.

\subsection{Government-Industry Coalition}

A post-boom coalition between Government and Industry to support half reforms implies that both players focus on maximising Industry's expected value, which depends on the real value of production. With lower subsidies, Industry's payoffs would increase through low input real prices so that production costs diminish. Industry also required stable domestic prices and a devalued real exchange rate to stimulate exports as well as new space in external markets.

Yet, Government cannot increase its expected value by raising Industry's expected value without lowering Coffee's expected value by playing with monetary variables. The tradeoff came from the inflationary pressures as the coffee boom would raise pressures on domestic prices and revaluate the real exchange rate. If Government offset these forces by keeping prices from going up, the domestic coffee price would have frozen, thus reducing Coffee's profits. The unambiguous alternative to increase Government's payoffs through industry was to reduce real input prices.

Nonetheless, these choices were not feasible for ALM's government. During the 1970s there were ongoing struggles among unions, firms and the government on real wages. The bargaining was complicated by the industrial productivity slowdown, ALM's compromise with the working class, increasing inflation and unions' reluctance to make labour legislation much more flexible. In consequence, no clear sign was given to entrepreneurs on this matter ${ }^{12}$. Besides, the negotiation on the Andean Pact lacked true members' commitment and stagnated in 1976 with Chile's withdrawal (Garay 1998, p. 326). Hence, a Government-Industry coalition was weakly grounded as it faced harsh constraints and had less means to contain Coffee's demands.

11 The main state reforms of the $20^{\text {th }}$ century were led by the political parties in power such as those in the 1930s and post-WWII (Ocampo 1996).

12 Kalmanovitz (1997, pp. 491-501). El Tiempo, 3 August 1976, p. 6A and 5 August 1976, p. 15A. 


\subsection{Government-Coffee Coalition}

From August 1974 until the end of 1975 legislation related to the reforms was active. However, once the coffee boom was well recognised during the first quarter of 1976, the economic legislation changed focus and concentrated on tightening the money supply and regulating coffee prices, coffee investments and the terms of convertibility of coffee assets. Despite official declarations assuring that the extraordinary inflow of foreign money would be held back, the domestic coffee price and the money supply grew at an annual rate of 45 per cent (Sánchez et al. 2007). In this way the GovernmentCoffee coalition begun taking shape, although it was officially signalled by the change of the minister of finance in December 1976 when ALM's government moved from a technocratic minister, withdrew from the industrial association to a political minister from the coffee association ${ }^{13}$.

Government announced that the benefits of the bonanza belong to the coffee growers, assuring them that there would not be higher taxes or other redistributive measures on extraordinary profits. The state only perceived 11 per cent of the bonanza profits at the same time that the sector managed to reduce its tax burden in 1977-1978 (Pécaut 1988, pp. 260-264). In return, Coffee would share its export income via the National Coffee Fund. This fund would serve as collateral for issuing public debt as well as for investment in developmental assets (Pagarés semestrales de emergencia Económica, Bonos de desarrollo económico, Bonos cafeteros 1975, among others) aimed at promoting other sectors ${ }^{14}$.

Meanwhile, hostile relationships, motivated by financial repression and trade openness, would grow between Industry and Government. In response, the coalition established compensatory payments; Government allocated resources to industrial firms via loans partly funded by Coffee's extra profits and applied measures for financial relief from which important textile producers such as Coltejer benefited. In addition, Government agreed several loans with the Bank for Reconstruction and Development to address Industry's capital needs ${ }^{15}$.

\subsubsection{Half-Hearted Economic Reforms}

Half reforms would promote a soft version of macroeconomic stabilisation and structural adjustment preventing inflation and fiscal deficit from

13 The first minister, Rodrigo Botero Montoya was a well-respected industrial and economist whose resignation was accepted on 23 December 1976. Abdón Espinosa Valderrama was appointed in his place. Diario Oficial, \# 34718, 7 February 1977, p. 257.

14 Diario Oficial: \#34566, 7 June 1976, p. 778; \#34568, 9 June 1976, p. 811; \#34600, 29 July 1976, p. 393; \#34643, 28 September 1976, p. 1082; \#34720, 9 February 1977, p. 292; \#34792, 25 May 1977, pp. 627-628; \#34843, 10 August 1977, p. 465; \#34884, 7 October 1977, p. 66; \#34931, 19 December 1977, p. 1082.

${ }_{15}$ El Tiempo, 9 August 1977, p. 9A and 9 September 1977, p. 15A. See also Diario Oficial: \#34536, 23 April 1976, p. 233; \#34613, 17 August, 1976, p. 614; \#34855, 10 October 1977, p. 98. 
reaching excessively high levels and selectively lowering trade barriers and subsidies. According to the equilibria in Table 3, under high coffee prices the coalition Government-Coffee has two probable paths to arrive at half reforms: FCD and HCD. The first path entails a more ambitious Government in regard to the scope of half reforms and a stronger capacity for persuading Coffee to bear most of the costs given Industry's defection. A central piece of evidence to evaluate Government's reformist aggressiveness after the coffee boom lies in monetary policy.

Table 4 shows the growth rates of the main economic indicators. It can be seen that from 1976 the rise in international coffee prices is translated into domestic coffee prices, the monetary base, and hence inflation which peaked at 40.5 per cent in June 1977. At the same time, fiscal spending and nominal devaluation of the exchange rate slowed down. While policymakers let domestic coffee prices rise, they contracted other sources of expansionary demand such as public spending, bank operations and nominal devaluation in order to contain inflation (Bejarano 1985, p. 140; Ocampo 1987, p. 318). Thus, Government followed a soft reform path.

Consequently, the real exchange rate appreciated while the activity of the financial sector shrank which damaged Industry. The financial sector had warned of the negative effects of tight monetary policies on the provision of credit and capital to firms as well as on financial intermediation (Cabrera 1982). These contractive measures were perceived as a financial counterreform that increased capital cost and financial repression ${ }^{16}$. Unionised workers had to struggle continuously for nominal increases of the minimum wage that compensated for past inflation. Despite their activity, the real minimum wage (pesos of 1988) went down from an average of 23.37 in the 1960s to 19.87 in 1970.

\subsubsection{The Sustainability of the Reforms}

The costs of the 1975 recession and the fiscal adjustment fell on the shoulders of state bureaucracy and workers. This approach continued after the coffee boom; state downsising, cuts in public spending and wage adjustments lower than inflation heated social hostility towards ALM's reforms.

When inflation went up beyond historical records, a myriad of civil protests and strikes burst out. Government's expected value went down along

${ }^{16}$ El Tiempo, 4 August 1976, p. 8A. Constraints to bank loans increased. The rate of required reserves for banks was raised from 35 to 46.5 per cent between 1974 and 1977 . Moreover, by 1977 this rate for additional deposits was 100 per cent (Pécaut 1988, p. 278). Bejarano (1985, p. 145) states that financial liberalisation would have been sustainable with a floating exchange rate, lower trade tariffs and increasing imports in response to large foreign reserves. Yet, Colombian policymakers in the 1970s could not rely on a free market of foreign money given their pre-crawling peg experiences (Garcia and Jayasuriya 1997). 
TABLE 4

ANNUAL GROWTH RATES OF MAIN ECONOMIC INDICATORS

\begin{tabular}{|c|c|c|c|c|c|c|c|c|c|c|}
\hline \multicolumn{2}{|c|}{ Date } & \multirow[b]{2}{*}{$\begin{array}{c}\text { Interna- } \\
\text { tional coffee } \\
\text { price }(\%)\end{array}$} & \multirow[b]{2}{*}{$\begin{array}{c}\text { Domestic } \\
\text { coffee } \\
\text { price }(\%)\end{array}$} & \multirow[b]{2}{*}{$\begin{array}{l}\text { M1 } \\
(\%)\end{array}$} & \multirow[b]{2}{*}{$\begin{array}{c}\text { Inflation } \\
(\%)\end{array}$} & \multirow[b]{2}{*}{$\begin{array}{c}\text { Nominal } \\
\text { devaluation } \\
(\%)\end{array}$} & \multirow[b]{2}{*}{$\begin{array}{c}\text { Central } \\
\text { government } \\
\text { spending/ } \\
\text { GDP }(\%)\end{array}$} & \multirow[b]{2}{*}{$\begin{array}{c}\text { Central } \\
\text { government } \\
\text { primary deficit/ } \\
\text { GDP }(\%)\end{array}$} & \multirow[b]{2}{*}{$\begin{array}{c}\text { GDP } \\
(\%)\end{array}$} & \multirow[b]{2}{*}{$\begin{array}{c}\text { Real } \\
\text { minimum } \\
\text { wage }(\%)\end{array}$} \\
\hline Year & Quarter & & & & & & & & & \\
\hline 1974 & $\begin{array}{l}\text { March } \\
\text { June } \\
\text { September } \\
\text { December }\end{array}$ & $\begin{array}{r}10.67 \\
12.00 \\
-8.99 \\
-8.70\end{array}$ & $\begin{array}{r}4.47 \\
14.01 \\
14.01 \\
25.39\end{array}$ & $\begin{array}{l}29.45 \\
22.51 \\
20.38 \\
19.51\end{array}$ & $\begin{array}{l}25.93 \\
22.33 \\
22.15 \\
26.04\end{array}$ & $\begin{array}{r}9.78 \\
8.89 \\
10.39 \\
15.49\end{array}$ & 10.27 & -1.16 & 6.43 & 44.24 \\
\hline 1975 & $\begin{array}{l}\text { March } \\
\text { June } \\
\text { September } \\
\text { December }\end{array}$ & $\begin{array}{r}-29.15 \\
-21.83 \\
46.41 \\
40.26\end{array}$ & $\begin{array}{r}25.94 \\
3.84 \\
32.57 \\
30.57\end{array}$ & $\begin{array}{l}19.80 \\
20.67 \\
26.19 \\
27.77\end{array}$ & $\begin{array}{l}24.39 \\
24.41 \\
23.47 \\
17.70\end{array}$ & $\begin{array}{l}17.24 \\
21.05 \\
20.51 \\
15.12\end{array}$ & 10.94 & -0.50 & 3.06 & -15.03 \\
\hline 1976 & $\begin{array}{l}\text { March } \\
\text { June } \\
\text { September } \\
\text { December }\end{array}$ & $\begin{array}{r}95.20 \\
161.66 \\
94.69 \\
145.29\end{array}$ & $\begin{array}{r}64.80 \\
158.64 \\
118.67 \\
115.38\end{array}$ & $\begin{array}{l}28.38 \\
29.92 \\
26.91 \\
34.75\end{array}$ & $\begin{array}{l}17.32 \\
17.92 \\
22.31 \\
25.68\end{array}$ & $\begin{array}{l}13.70 \\
11.94 \\
10.21 \\
10.19\end{array}$ & 9.37 & 0.62 & 5.40 & 4.01 \\
\hline 1977 & $\begin{array}{l}\text { March } \\
\text { June } \\
\text { September } \\
\text { December }\end{array}$ & $\begin{array}{r}201.35 \\
74.22 \\
19.02 \\
-2.05\end{array}$ & $\begin{array}{r}69.90 \\
20.11 \\
11.28 \\
4.29\end{array}$ & $\begin{array}{l}33.61 \\
44.15 \\
38.90 \\
30.39\end{array}$ & $\begin{array}{l}29.49 \\
40.55 \\
34.14 \\
28.37\end{array}$ & $\begin{array}{l}7.78 \\
5.19 \\
5.24 \\
4.52\end{array}$ & 8.84 & 0.50 & 4.88 & 16.17 \\
\hline 1978 & $\begin{array}{l}\text { March } \\
\text { June } \\
\text { September } \\
\text { December }\end{array}$ & $\begin{array}{l}-42.16 \\
-35.44 \\
-18.08 \\
-35.03\end{array}$ & $\begin{array}{l}4.29 \\
0.00 \\
0.00 \\
0.00\end{array}$ & $\begin{array}{l}29.34 \\
25.53 \\
31.93 \\
30.29\end{array}$ & $\begin{array}{l}23.46 \\
14.74 \\
14.10 \\
18.77\end{array}$ & $\begin{array}{l}5.00 \\
6.49 \\
7.03 \\
8.01\end{array}$ & 9.27 & 0.30 & 9.11 & -7.13 \\
\hline 1979 & $\begin{array}{l}\text { March } \\
\text { June } \\
\text { September } \\
\text { December }\end{array}$ & $\begin{array}{r}-25.29 \\
14.48 \\
32.97 \\
47.50\end{array}$ & $\begin{array}{r}-12.33 \\
-4.84 \\
5.66 \\
12.55\end{array}$ & $\begin{array}{l}23.01 \\
25.02 \\
23.85 \\
24.29\end{array}$ & $\begin{array}{l}22.74 \\
21.90 \\
27.70 \\
28.80\end{array}$ & $\begin{array}{l}9.37 \\
9.88 \\
8.18 \\
7.32\end{array}$ & 9.83 & -0.74 & 6.01 & 3.81 \\
\hline
\end{tabular}

Sources: GRECO (2002), Banco de la República (1998) and FEDECAFE. 
with workers' expected income. The period 1975-1977 registered the highest number of strikes along with civil protests that ended violently in which protesters' radicalisation could not always be controlled by the unions themselves (Pécaut 1988, pp. 301-313; Ocampo 1996, p. 327).

Furthermore, ALM faced a latent threat of instability from left-leaning forces because of discontent with land reform. The government ruled under a constant state of siege from mid-1975 in an attempt to maintain public order. By 1978 ALM's government had clearly lost the support of workers and peasants.

Tensions between the executive, the traditional political class and military forces were also running high. The role of military forces and their internal division at the advent of a generalised moral crisis in Colombian society, as Pécaut puts it, was symptomatic of the deteriorated legitimacy of ALM's government, especially after the coffee boom, as was the instability of the presidential staff shown by the unusually high turnover of ministers; thirtythree ministers in 4 years (Posada 1989).

Such a moral crisis was reflected in corruption scandals involving not only the presidential family but also the political houses, the traditional parties and the entire political system (Ardila 1978; Pécaut 1988, pp. 293301). Hartlyn (1993) reads this situation as the legacy of the Frente Nacional, which often concentrated too much on struggles over the allocation of state bureaucracy and resources. Ultimately social unrest, the crisis in the political system, and Government's poor coordination were fragile ground for the economic reforms.

\section{CONCLUSIONS}

The economic reforms in 1970s Colombia emerged in a challenging context. From 1970 onwards, the economic and political dynamics drove the leading economic sectors and the government to question the ISI model and redefine the rules of the game. Coffee lost part of its relatively dominant position and Industry experienced expansionist incentives from the external and internal markets, while Government strengthened its position by widening its electoral base and technocratic support. This change in relative power can be read as the beginning of a rupture between elites where the scope of economic and political rights was amplified. Therein lays the inclusion of demands for industrial expansion as well as other social demands.

The analytic narrative developed here places the strategic interactions between Government, Coffee and Industry at the centre of the epoch. The main uncertainty in this scenario comes from the 1976 coffee boom, which is projected in the game as nature's play. I state that before the boom, the sectors' strategic interaction could be seen as an assurance game, while such 
interaction is best interpreted as a prisoner's dilemma after the boom. The setup also portrays Government as an agenda setter that weighed Coffee's interests more heavily and did not modify its reform valuations in light of the coffee boom.

I provided historical facts to substantiate this game and apply simple decision rules to rank player' payoffs in order to determine Nash and coalitional equilibria. The analytic narrative uses history to make sense of theoretical insights as well as to establish the reform path actually chosen. In the post-boom scenario, two identifiable coalitions emerge, but using related evidence only the Government-Coffee coalition and its choice of half reforms as the factual reform path stands out. Half reforms included fiscal tightening and a reduction of the fiscal deficit, some degree of state downsising, and selective trade liberalisation. Other policies applied that went against the full reformist endeavor were high inflation, regressive taxation and financial repression.

As a result, Coffee and Government's short-run interests prevailed over those of Industry and the workers. The non-neutrality of Government certainly rested on limited state autonomy. However, state autonomy is a dynamic variable enlarged or shrunk through a process of institutional change led by groups of individuals. The agenda setter's skills are also critical in determining the direction of the institutional change. In this sense, the role of ALM's government exhibited a poor understanding of the dilemmas posed by the coffee boom; also it somehow wasted the opportunity to dislocate Coffee, opened up by Industry and, to some extent, the workers. The key role of specific individuals who grasp the game's nature, deal with uncertainty, and provide meaningful leadership is to be found here.

How well does this analytic narrative explain the reform epoch? As Bates et al. (1998) remind us, evaluating an analytic narrative is not a matter of falsification but of sound reasoning and rigorous documentation. Even with these features, multiple explanations could persist. For example, simplifying assumptions such as Government's commitment to full reforms can be questioned. The actions of ALM's government could be read as incoherent and representative of a structurally weak state, so that factual reforms would be explained mainly by a coffee sector able to influence macroeconomic policies and a private sector (not only Industry) not ready to abandon the ISI policy regime. Another competing explanation puts heavy weight on the coffee boom, asserting that the boom blocked the way to full reforms towards which ALM's government was decidedly driving the country.

I contend that these explanations greatly simplify what was happening in the country. The first view depicts Government as a mute guest and economic sectors as fully capable of imposing their best interests. By examining the main players' discourses and actions, the 1970s presented a complex and problematic policy setting, revealing clashes of interests as well as the struggle of Government to strengthen its state capacity. In addition, placing 
all responsibility on the coffee boom and assuming that full reforms could have been adopted otherwise, neglects the coordinating difficulties faced by Government even before the boom. Furthermore, under the generous assumption that economic sectors were willing to adopt full reforms and cooperate before the boom, such an outcome was as unlikely as the CoffeeIndustry coalition.

Another criticism could point out that the reasoning is incomplete as players such as workers or peasants were not included in the game. However, this simplification would not substantially change the predicted outcomes; more likely it would increase the number of equilibria. The key point this analytic narrative does stress is that the support of workers was important to Government's expected value; once policy measures started hurting workers, the sustainability of the reforms was even more compromised. It is not surprising that the chosen reform path turned out to be an unstable equilibrium, confirmed by the protectionist policymaking of the governments of the1980s. The definitive move to market liberalisation would have to wait until the 1990s although under different strategic interactions and reform agendas.

\section{SUPPLEMENTARY MATERIAL}

To view supplementary material for this article, please visit http://dx.doi. org/10.1017/S0212610915000166.

\section{REFERENCES}

ARdila, P. (1978): El negocio oscuro del mandato claro. Bogotá: CINEP.

Banco de la República (1998): Principales indicadores económicos 1923-1997. Santafé de Bogotá: Banco de la República, subgerencia de estudios económicos.

Barrios, A.; Henao, M.; Posada, C.; Valderrama, F., and Vasquez, D. (1993): «Empleo y capital en Colombia: nuevas estimaciones (1950-1992)», Archivos de Macroeconomía No. 15, DNP, Santafe de Bogotá.

Bates, R.; Greif, A.; Levi, M.; Rosenthal, J. L., and Weingast, B. (1998): Analytic Narratives. Princeton, NJ: Princeton University Press.

Bates, R., and Krueger, A. (1993): Political and Economic Interactions in Economic Policy Reform: Evidence from Eight Countries. Oxford, UK and Cambridge, MA: Blackwell.

Bejarano, A. M. (2011): Democracias precarias: Trayectorias politicas divergentes en Colombia y Venezuela. Bogotá: Universidad de los Andes.

Bejarano, J. A. (1984): La economía colombiana en la década del 70. Bogotá: Fondo Editorial CEREC.

BeJARANo, J. A. (ed.) (1985): Lecturas sobre economía colombiana: Siglo XX. Bogotá: Procultura.

Berry, A.; Hellman, R., and Solaun, M. (1980): Politics of Compromise: Coalition Government in Colombia. New Brunswick, NJ: Transaction Books.

Bulmer-Thomas, V. (1994): The Economic History of Latin America Since Independence. Cambridge, England and New York: Cambridge University Press. 
Cabrera, M. (1980): Sistema financiero y Políticas antiinflacionarios: 1974-1980. Bogotá: Asociación Bancaria de Colombia, Editorial Presencia.

CABrera, M. (1982): Sistema financiero y desarrollo en Colombia. Bogotá: Universidad Nacional de Colombia, Departamento de Economía.

Clavijo, S. (1992): "Overcoming Financial Crisis During Transition from a Repressed to a Market-Based System: Colombia, 1970-89», in A. Cohen, and F. R. Gunter (eds), The Colombian Economy: Issues of Trade and Development. Boulder, Colo: Westview Press, pp. 93-118.

Cochinard, S. (2002): «The Coalition Concept in Game Theory», in C. Schmidt (ed.), Game Theory and Economic Analysis. London and New York: Routledge, pp. 90-113.

ECHEVERRI, A. (1987): Elites y proceso político en Colombia (1950-1978): Una democracia principesca y endogámica, régimen político colombiano en los últimos treinta años. Bogotá: Fundación Universitaria Autónoma de Colombia.

Edwards, S. (2001): The Economics and Politics of Transition to an Open Market Economy: Colombia. Paris: Development Centre Studies, OECD Publishing.

Federación NAcional de Cafeteros (FEDECAFE) (2010): Estadísticas Históricas. Available at http://www.federaciondecafeteros.org/particulares/es/quienes_somos/ 119_estadisticas_historicas/

GARAY, J. (1998): «Colombia: estructura industrial e internacionalización 1967-1996», in J. Garay (ed.), La industria en América Latina ante la globalización económica. Bogotá: Conciencias.

GARCIA, J., and JAYASURIYA, S. (1997): Courting Turmoil and Deferring Prosperity: Colombia Between 1960 and 1990. Washington, DC: World Bank.

Gómez, H. (1978): Alfonso López Michelsen: Un examen crítico de su pensamiento y su obra de gobierno. Bogotá: Editorial Tercer Mundo.

Gómez, H., and Leibovich, J. (1987): «El impacto de la política macroeconómica sobre las regiones cafeteras», in J. A. Ocampo (ed.), Lecturas de economía cafetera. Bogotá: Fedesarrollo, Tercer Mundo Editores, pp. 231-250.

GRUPO DE ESTUdIOS DEL CRECIMIENTO ECONÓMICO COLOMBIANO (GRECO) (2002): El crecimiento económico colombiano en el siglo XX. Bogotá: Banco de la República, Fondo de Cultura Económica.

GreIF, A. (2002): «Economic History and Game Theory», in R. Aumman, and S. Hart (eds), Handbook of Game Theory, vol. 3. Amsterdam: Elsevier, pp. 1988-2024.

HaRtLyn, J. (1993): La política del régimen de coalición: La experiencia del Frente Nacional en Colombia. Bogota: Uniandes.

Junguito, R., and Rincon, H. (2007): «La política fiscal en el siglo XX en Colombia», in J. Robinson, and M. Urrutia (eds), Economía Colombiana del Siglo XX. Bogotá: Banco de la República, FCE, pp. 239-312.

Kalmanovitz, S. (1997): Economía y Nación. Bogotá: TM Editores.

Krueger, A. (2000): «Introduction», in A. Krueger (ed.), Economic Policy Reform. The Second Stage. Chicago: University of Chicago Press, pp. 3-20.

López, A. (1975): El Gobierno del Mandato Claro. Bogotá: Imprenta Nacional de Colombia.

Mares, D. (1988): «Middle Powers under Regional Hegemony: To Challenge or Acquiesce in Hegemonic Enforcement». International Studies Quarterly, 32, 453-471.

Mares, D. (1993): «State Leadership in Economic Policy: A Collective Action Framework with a Colombia Case». Comparative Politics 4, 455-473.

Martínez, A. (1986): La estructura arancelaria y las estrategias de industrialización en Colombia 1950-1982. Bogotá: Centro de Investigaciones para el Desarrollo, CID, Universidad Nacional. 
Misas, G. (1980): La política de liberación de importaciones en el caso colombiano: 19741980. Medellín: Universidad de Antioquia.

Nelson, R.; Schultz, P., and Slighton, R. (1971): Structural Change in a Developing Economy. Colombia's Problems and Prospects. NJ: Princeton University Press.

Ocampo, J. A. (ed.) (1987): Lecturas de economía cafetera. Bogotá: Fedesarrollo, Tercer Mundo Editores.

Ocampo, J. A. (ed.) (1996): Historia económica de Colombia. Bogotá: TM Editores: Fedesarrollo.

Palacios, M. (1983): El café en Colombia, 1850-1970: una historia económica, social y politica. México, DF/Bogotá, Colombia: Colegio de México/Ancora Editores.

Pecaut, D. (1988): Crónica de dos decadas de politica colombiana, 1968-1988. México, DF: Siglo Veintiuno Editores.

Posada, I. (1989): Presidentes de Colombia 1810-1990. Bogotá: Editorial Planeta.

SAEnZ, E. (2002): Colombia años 50: industriales, politica y diplomacia. Bogotá: Universidad Nacional de Colombia.

Sanchez, F.; Fernandez, A., and ARmenta, A. (2007): «Historia monetaria de Colombia en el siglo XX: Grandes tendencias y episodios relevantes», in J. Robinson, and M. Urrutia (eds), Economía Colombiana del Siglo XX. Bogotá: Banco de la República, FCE, pp. 313-382.

Silva, G. (1989): «Carlos Lleras y Misael Pastrana: reforma del estado y crisis del Frente Nacional», in A. TIRADO (ed.) Nueva Historia de Colombia. vol. II. Bogotá: Editorial Planeta, pp. 237-262.

Tsebelis, G. (1990): Nested Games: Rational Choice in Comparative Politics. Berkeley: University of California Press.

URrutia, M. (1983): Gremios, política económica y democracia. Bogotá: Fedesarrollo, Fondo Cultural Cafetero.

World BANK (2003): World Development Indicators. Washington: World Bank.

\section{SOURCES}

Diario Oficial. 1974-1978. Bogotá: Imprenta Nacional.

El Tiempo, 1974-1978, Bogotá. 